\title{
PENGARUH PUBLIC OWNERSHIP DAN GROWTH OPTION TERHADAP KINERJA KEBERLANJUTAN DENGAN INVESTMENT OPPORTUNITY SET SEBAGAI VARIABEL MODERASI
}

\author{
Endang Ruhiyat ${ }^{1)}$; Holiawati ${ }^{2)}$ \\ Universitas Pamulang \\ holiawati76@gmail.com
}

\begin{abstract}
This study aims to determine the effect of public ownership and growth options on sustainability performance with an investment opportunity set as a moderating variable. This type of research is associative quantitative using secondary data taken from the IDX website. The population in this study is manufacturing companies listed on the Indonesia Stock Exchange from 2013 to the end of 2017. The sample selection procedure in this study is using purposive sampling method, only 50 company data that meet the criteria. The results of this study have a significant effect on Public Ownership Sustainability Performance, the influence of growth options on sustainability performance. Opportunity Set is able to moderate the influence of Public Ownership on Sustainability Performance. The Investment Opportunity Set does not moderate the effect of Growth Options on Sustainability Performance.
\end{abstract}

Keywords : Public Ownership; Growth Option; Sustainability Performance; Opportunity Set

\begin{abstract}
Abstrak
Penelitian ini bertujuan mengetahui pengaruh public ownership dan growth option terhadap kinerja keberlanjutan dengan investment opportunity set sebagai variabel moderasi. Jenis Penelitian ini adalah kuantitatif asosiatif dengan menggunakan data sekunder yang diambil dari situs BEI. Populasi dalam penelitian ini adalah perusahaan manufaktur yang tercatat di Bursa Efek Indonesia mulai tahun 2013 sampai akhir tahun 2017. Prosedur pemilihan sampel pada penelitian ini adalah menggunakan metode purposive sampling, hanya 50 data perusahaan yang memenuhi kriteria. Hasil penelitian ini Public Ownership berpengaruh signifikan terhadap Kinerja Keberlanjutan, adanya pengaruh growth option terhadap Kinerja Keberlanjutan, . Opportunity Set mampu memoderasi pengaruh Public Ownership terhadap Kinerja Keberlanjutan, Investment Opportunity Set tidak memoderasi pengaruh Growth Option terhadap Kinerja Keberlanjutan.
\end{abstract}

Kata Kunci : Public Ownership; Growth Option; Kinerja Keberlanjutan; Opportunity Set 
Jurnal Akuntansi Berkelanjutan Indonesia - Vol. 3, No. 2, Mei 2020 - Ruhiyat \& Holiawati

\section{PENDAHULUAN}

Kinerja Keberlanjutan biasanya dapat dikatakan juga sebagai Sustainability Performance dipahami sebagai perwujudan komitmen kepada Corporate Social Responsibility atau yang biasa disingkat CSR. Menurut Suharto (2008) dalam Puspita (2014) CSR merupakan suatu bentuk kepedulian perusahaan dalam menyisihkan sebagian keuntungannya untuk kepentingan pembangunan manusia dan lingkungan berdasarkan prosedur yang tepat dan professional. Keberlangsungan hidup perusahaan hanya akan terjadi apabila perusahaan peduli terhadap pertumbuhan ekonomi, pengembangan lingkungan, dan terhadap

Kinerja keberlanjutan dapat dipengaruhi oleh beberapa aktivitas operasional dan aktivitas non operasional perusahaan, seperti peluang investasi yang ditandai dengan growth option serta penyebaran saham dengan public ownership. Dari penelitian sebelumnya yaitu menurut Bart Manning, Geert Braam, dan Daniel Remsbach (2017) menemukan, bahwa Public Ownership berpengaruh signifikan terhadap Sustainability Performance. Ardiyani Puspita (2014) menemukan, bahwa Growth Option dan Public Ownership berpengaruh positif terhadap Sustainability Performance. Menurut Isabel Lourenco dan Manuel Castelo (2013) menemukan, bahwa Growth Option dan Public Ownership berpengaruh negative terhadap Sustainability Performance, menurut Tracy Artiach, Darren Lee, David Nelson, dkk. (2010) menemukan, bahwa Growth Option berpengaruh positif tehadap Sustainability Performance.

Instment Opportunity Set (IOS) merupakan salah satu pilihan kesempatan berinvestasi di masa yang akan datang atau masa depan yang dapat mempengaruhi pertumbuhan aktiva perusahaan atau proyek - proyek perusahaan yang memiliki net present value yang positive. Oleh karna itu IOS memiliki peranan yang demikian penting bagi kinerja perusahaan karena IOS adalah sebuah keputusan investasi dalam bentuk kombinasi dari aktiva yang dimiliki dan opsi investasi di masa yang akan datang, dimana IOS tersebut akan mempengaruhi nilai dan kinerja sebuah perusahaan (Pagalung, 2003) dalam Sufi Fajrotus Syifa (2015). Menurut Gaver dan Gaver (1993) dalam Arka Pradipta Budi Dharma (2014), Investment Opportunity Set (IOS) merupakan suatu nilai perusahaan yang besarnya tergantung pengeluaran - pengeluaran yang ditetapkan oleh manajemen di masa yang akan datang, yang pada saat ini merupakan pilihan - pilihan investasi yang diharapkan akan menghasilkan return yang lebih besar bagi perusahaan. Investment Opportunity set dapat dikatakan sebagai sebuah set kesempatan investasi yang harus diperhatikan oleh manajemen perusahaan dalam rangka melihat kesempatan yang ada dan memanfaatkannya untuk peningkatan kinerja dari perusahaan tersebut di masa yang akan datang agar terus berkembang dan bertahan secara berkesinambungan. Karna itu setiap manajemen haruslah mampu mengambil keputusan yang tepat dan menimbang berbagai aspek yang ada. Dan Investment Opportunity set ini sangat erat hubungannya dengan Kinerja yang bersifat keberlanjutan dalam sebuah organisasi atau perusahaan.

Alasan dilakukannya penelitian ini yaitu karena perekonomian global sudah menjadi sangat ketat dan konsep green economy yang telah dicanangkan sejak lama perlahan mulai diterapkan oleh perusahaan-perusahaan, sehingga

* Corresponding author's e-mail:holiawati76@gmail.com http://openjournal.unpam.ac.id/index.php/JABI 
Jurnal Akuntansi Berkelanjutan Indonesia - Vol. 3, No. 2, Mei 2020 - Ruhiyat \& Holiawati

perusahaan dituntut untuk segera beradaptasi pada lingkungan. Lingkungan yang dimaksud di sini berupa lingkungan ekonomi, sosial, dan budaya secara beriringan. Selain itu, di Indonesia saat ini masih banyak perusahaan yang belum menyadari betapa pentingnya kinerja keberlanjutan, oleh karena itu dalam penelitian ini akan dijelaskan seberapa pentingnya kinerja keberlanjutan dan beberapa hal yang dapat mempengaruhi kinerja keberlanjutan perusahaan itu sendiri.

\section{KERANGKA TEORITIS DAN PENGEMBANGAN HIPOTESIS}

Freeman (1984) mengatakan bahwa Stakeholders adalah kelompok atau individu yang dapat memberi dampak kepada organisasi serta atau dipengaruhi oleh organisasi sebagai akibat dari aktivitas-aktivitasnya. Ghozali dan Chariri (2007) menyatakan bahwa perusahaan dapat memberi manfaat untuk stakeholders-nya (kreditor, shareholders, supplier, pelanggan, masyarakat, pemerintah, analisis dan berbagai pihak ) sehingga perusahaan bukan entitas yang beroperasi hanya untuk kepentingannya sendiri. Perusahaan akan melaksanakan pengungkapan informasi yang berkaitan dengan kinerja lingkungan, sosial, dan ekonomi untuk memenuhi ekspektasi dari stakeholder. Pengungkapan ini berguna untuk membantu manajer agar mengerti lingkungan stakeholder dan melakukan pengelolaan efektif hubungan-hubungan yang ada di lingkungan perusahaan mereka.

\section{Pengaruh Public Ownership terhadap Kinerja Keberlanjutan}

Ketika saham perusahaan dimiliki oleh banyak pihak, sehingga akuntabilitas publik dapat menjadi lebih penting karena perusahaan-perusahaan ini sedang dipegang oleh masyarakat luas. Tingkat akuntabilitas publik yang lebih tinggi akan memerlukan keterlibatan lebih dalam kegiatan sosial atau lingkungan yang bertanggung jawab (Ghazali, 2007 dalam Puspita, 2014). Penyebaran kepemilikan dengan adanya kepemilikan publik yang besar mengakibatkan pengawasan tidak hanya bertumpu pada kelompok tertentu, sehingga pengawasan terhadap debt atau utang menjadi lebih ketat.

Jian Chen (2001) dalam Puspita (2014) menyatakan bahwa kepemilikan yang menyebar dapat berperan penting dalam perusahaan. Kepemilikan yang menyebar akan mudah untuk dilakukan monitoring, dan meningkatkan firm value. Karena dengan kepemilikan yang menyebar berarti adanya insentif untuk mengumpulkan informasi dan monitoring terhadap manajemen, dan mengurangi adanya penyimpangan-penyimpangan. Sánchez et al (2011) dalam Puspita (2014) menunjukkan bahwa tatakelola perusahaan akan lebih peka dalam menanggapi masalah sosial ketika kepemilikan perusahaan lebih tersebar, karena investor sosial lebih mungkin untuk campur tangan dalam proses pembuatan keputusan perusahaan. Maka konsentrasi public ownership diduga berpengaruh terhadap kinerja keberlanjutan.

Hipotesis ini didukung penelitian terdahulu sebelumnya oleh Isabel Lourenco dan Manuel Castelo (2013) tentang analisis faktor-faktor yang mempengaruhi 
Jurnal Akuntansi Berkelanjutan Indonesia - Vol. 3, No. 2, Mei 2020 - Ruhiyat \& Holiawati

kinerja keberlanjutan perusahaan mengenai pengaruh ukuran perusahaan, leverage, profitabilitas, growth option, public ownership, dan international listing terhadap kinerja keberlanjutan perusahaan, yang menyatakan bahwa public ownership tidak berpengaruh terhadap kinerja keberlanjutan.

Public Ownership merupakan kepemilikan saham yang dimiliki oleh publik yang menuju kepada stakeholder. Stakeholder merupakan pihak internal maupun pihak eksternal perusahaan baik yang berhubungan secara langsung oleh prusahaan maupun tidak. Namun public ownership merupakan kepemilikan saham yang tidak memiliki hubungan secara langsung dengan perusahaan yang keberadaannya sangat mempengaruhi dan dipengaruhi perusahaan apabila kepemilikannya menyebar secara luas. Hal ini berkaitan dengan teori stakeholder dan teori legitimasi bahwa perusahaan perlu menjaga legitimasi stakeholder serta menempatkannya dalam kerangka kebijakan dan pengambilan keputusan, sehingga dapat mendukung tercapainya tujuan perusahaan yaitu perusahaan yang going concern.

Berdasarkan uraian hasil penelitian diatas maka dapat dirumuskan hipotesis kedua.

H2 : Terdapat pengaruh antara Public Ownership terhadap Kinerja Keberlanjutan.

\section{Pengaruh Growth Option terhadap Kinerja Keberlanjutan}

Growth option ditandai dengan investasi perusahaan yang juga merupakan indikator kinerja keberlanjutan perusahaan. Semakin tinggi investasi perusahaan terusebut otomatis semakin tinggi pula growth option yang dialami perusahaan. Dengan growth option yang meningkat tersebut akan semakin mendorong perusahaaan dalam mengimplementasikan kinerja keberlanjutan dalam perusahaan. Hal ini berarti pula, semakin besar kemungkinan perusahaan tersebut mampu menggabungkan prinsip-prinsip keberlanjutan (sustainability) ke dalam strategi kompetitif atau persaingan. Growth option juga akan mempengaruhi tingkat investasi masing-masing perusahaan dalam riset dan pengembangannya, yang juga diharapkan akan terkait dengan kinerja keberlanjutan perusahaan (McWilliams dan Siegel, 2000 dalam Puspita, 2014).

Hipotesis ini didukung penelitian terdahulu sebelumnya oleh Anitya Ardiyani Puspita dan Daljono (2014) tentang analisis faktor-faktor yang mempengaruhi kinerja keberlanjutan perusahaan mengenai pengaruh ukuran perusahaan, leverage, profitabilitas, growth option, komitmen perusahaan, kepemilikan publik, dan umur perusahaan terhadap kinerja keberlanjutan perusahaan, yang menyatakan bahwa growth option berpengaruh positif terhadap kinerja keberlanjutan.

Growth Option merupakan luasnya kesempatan atau peluang investasi yang menuju kepada stakeholder. Stakeholder merupakan pihak internal maupun pihak eksternal perusahaan, seperti pemerintah, perusahaan asing, masyarakat sekitar, lembaga diluar perusahaan (LSM dan sejenisnya), lembaga pemerhati lingkungan, para pekerja perusahaan, dan sebagainya yang keberadaannya sangat mempengaruhi dan dipengaruhi perusahaan. Hal ini berkaitan dengan teori stakeholder dan teori legitimasi bahwa perusahaan perlu menjaga legitimasi stakeholder serta menempatkannya dalam kerangka kebijakan dan pengambilan

* Corresponding author's e-mail:holiawati76@gmail.com http://openjournal.unpam.ac.id/index.php/JABI 
Jurnal Akuntansi Berkelanjutan Indonesia - Vol. 3, No. 2, Mei 2020 - Ruhiyat \& Holiawati

keputusan, sehingga dapat mendukung dalam pencapaian tujuan perusahaan yaitu stabilitas usaha dan going concern.

Berdasarkan uraian hasil penelitian di atas maka dapat dirumuskan hipotesis pertama.

H1 : Terdapat pengaruh antara Growth Option terhadap Kinerja Keberlanjutan.

\section{Pengaruh Invesment Oppotunity Set Memoderasi Pengaruh Growth Option dan Public Ownership Terhadap Kinerja Keberlanjutan.}

Investment Opportunity Set (IOS) adalah sebuah nilai kesempatan investasi yang merupakan nilai sekarang dari pilihan-pilihan perusahaan untuk membuat investasi dimasa yang akan terjadi. Pilihan investasi adalah suatu kesempatan untuk berkembang, namun seringnya perusahaan tidak selalu dapat melaksanakan semua kesempatan investasi dimasa yang akan datang. Bagi perusahaanperusahaan yang tidak mampu menggunakan kesempatan investasi tersebut akan mengalami semua pengeluaran yang lebih tinggi dibandingkan dengan kesempatan yang hilang. Secara umum IOS menggambarkan tentang luasnya kesempatan investasi bagi suatu perusahaan, namun sangat bergantung pada pilihan expenditure perusahaan untuk kepentingan di masa yang akan datang. Penelitian ini mendukung penelitian dari Septiandi Dwi Nugroho (2016) dan Sinta Amelia Yusri (2017) yang menunjukkan bahwa adanya analisis rasio IOS yang baik serta pengambilan keputusan mengenai kesempatan set investasi yang ada maka akan sangat berpengaruh bagi kemajuan dan kelangsungan perusahaan dimasa yang akan datang. Karna kesempatan yang tidak digunakan dengan baik maka bisa jadi akibatnya lebih buruk dan lebih merugikan jika dibandingkan dengan kesempatan yang hilang.

Jadi semakin bagus rasio IOS dalam suatu perusahaan maka akan semakin bagus juga kinerja keberlanjutan yang dimiliki oleh perusahaan tersebut. Hipotesis ini didukung oleh penelitian Bart Manning, Geert Braam, dan Daniel Remsbach (2017) tentang Corporate Governance and Sustainable Business Conduct Effects of Board Monitoring Effectivenesss and Stakeholder Engagement on Corporate Sustainability Performance and Disclosure Choices. Menyatakan bahwa public ownership berpengaruh signifikan terhadap kinerja keberlanjutan perusahaan. Begitupun dengan penelitian yang didukung oleh Tracy Artiach, Darren Lee, David Nelson, dkk. (2010) tentang The Determinants of Corporate Sustainability Performance. Menyatakan bahwa growth option berpengaruh tehadap kinerja keberlanjutan.

Growth Option yaitu luasnya kesempatan atau peluang investasi. Public Ownership adalah kepemilikan saham yang dimiliki oleh public. Growth option dan public ownership merupakan hal yang berbeda yang masing-masingnya saling menuju kepada stakeholder. Stakeholder merupakan pihak internal maupun pihak eksternal perusahaan, baik secara langsung maupun secara tidak langsung berkaitan dengan perusahaan yang keberadaannya sangat mempengaruhi dan dipengaruhi perusahaan. Hal ini berkaitan dengan teori stakeholder dan teori legitimasi bahwa perusahaan perlu menjaga legitimasi stakeholder serta menempatkannya dalam kerangka kebijakan dan pengambilan keputusan, sehingga dapat mendukung dalam pencapaian tujuan perusahaan yaitu stabilitas

* Corresponding author's e-mail:holiawati76@gmail.com http://openjournal.unpam.ac.id/index.php/JABI 
Jurnal Akuntansi Berkelanjutan Indonesia - Vol. 3, No. 2, Mei 2020 - Ruhiyat \& Holiawati

usaha dan going concern sehingga praktik keberlanjutannya dapat terus meningkat. Berdasarkan uraian diatas maka dapat dirumuskan hipotesis pertama penelitian ini adalah:

H3 : Invesment oppotunity set memoderasi pengaruh Public Ownership terhadap kinerja keberlanjutan

H4 :Invesment oppotunity set memoderasi pengaruh Growth Option terhadap kinerja keberlanjutan

\section{METODE RISET}

\section{Populasi dan Sampel}

Populasi dalam penelitian ini adalah perusahaan manufaktur yang tercatat di Bursa Efek Indonesia mulai tahun 2013 sampai akhir tahun 2017. Prosedur pemilihan sampel pada penelitian ini adalah menggunakan metode purposive sampling. Metode ini dilakukan dengan mengambil data-data yang terpilih oleh peneliti menurut ciri-ciri khusus yang dimiliki oleh sampel tersebut. Sampel yang purposive adalah sampel yang dipilih dengan cermat sehingga relevan dengan rancangan penelitian, hanya 50 data perusahaan yang memenuhi kriteria dibawah ini. Sampel penelitian diambil dengan kriteria sebagai berikut :

1. Perusahaan manufaktur yang tercatat di Bursa Efek indonesia 2013 - 2017.

2. Perusahaan telah menjadi anggota di Bursa Efek Indonesia minimal 6 tahun, dikarenakan periode penelitian selama 5 tahun.

3. Perusahaan yang menerbitkan laporan keuangan tahunan dalam mata uang rupiah pada tahun 2012-2017.

4. Perusahaan manufaktur yang tercatat di BEI yang memiliki data penelitian dengan lengkap terkait laporan tahunan (annual report) dan laporan keuangan pada periode pengamatan tahun 2013 - 2017.

\section{Operasional Variabel \\ Kinerja Keberlanjutan}

Pengukuran Kinerja Keberlanjutan menggunakan Balanced Scorecard. Balanced Scorecard merupakan suatu sistem manajemen strategi yang menjabarkan visi dan strategi suatu perusahaan ke dalam tujuan operasional dan tolak ukur. Pengukuran balanced scorecard dalam penelitian ini memiliki enam perspektif, yaitu perspektif keuangan, perspektif pelanggan, perspektif proses bisnis internal, perspektif pembelajaran dan pertumbuhan, perspektif sosial, serta perspektif lingkungan. Perspektif sosial dan perspektif lingkungan diadopsi dari Global Reporting Initiative (GRI) yang berkaitan dengan judul penelitian yaitu kinerja keberlanjutan.

1. Perspektif Keuangan dengan mengukur ROE, ROA, OI, EC dan TATO

2. Perspektif Pelanggan dengan mengukur Penerimaan dari Pelanggan

3. Perspektif Proses Bisnis Intenal dengan mengukur Penghasilan dari Operasi

4. Perspektif Pembelajaran dan Pertumbuhan mengukur efesiensi karyawan

5. Perspektif Lingkungan dengan melihat pengungkapan lingkungan yang dilakukan perusahaan dengan berdasarkan GRI standar dengan 8 indikator 
Jurnal Akuntansi Berkelanjutan Indonesia - Vol. 3, No. 2, Mei 2020 - Ruhiyat \& Holiawati

6.Perspektif Sosial dengan melihat pengungkapan lingkungan yang dilakukan perusahaan dengan berdasarkan GRI standar dengan 19 indikator

\section{Public Ownership}

Public ownership merupakan proporsi kepemilikan saham yang dimiliki oleh publik atau masyarakat terhadap saham perusahaan. Semakin besar proporsi kepemilikan saham publik, semakin banyak pihak yang membutuhkan informasi tentang perusahaan, sehingga banyak pula butir-butir informasi yang diungkapkan dalam laporan tahunan.

Rumusnya adalah sebagai berikut :

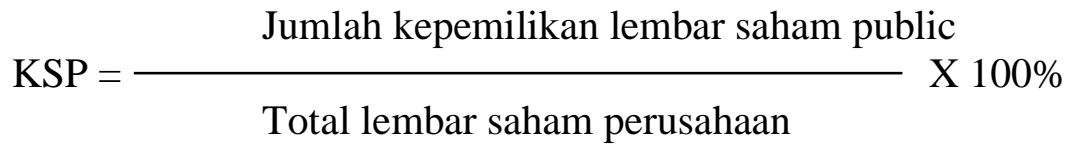

\section{Growth Option}

Growth Option merupakan sesuatu yang menggambarkan tentang luasnya kesempatan atau peluang investasi bagi suatu perusahaan. Growth option ditandai dengan investasi perusahaan yang juga merupakan indikator CSP. Semakin tinggi investasi perusahaan tersebut otomatis semakin tinggi pula growth option perusahaan.

Rumusnya adalah sebagai berikut :

$$
\text { PBV }=\frac{\text { Harga pasar saham }}{\text { Nilai buku per lembar saham }}
$$

\section{Investment Opportunity Set (IOS)}

Investment opportunity Set (IOS) merupakan keputusan investasi dalam bentuk kombinasi dari aktiva yang dimiliki dan opsi investasi dimasa yang akan datang, dimana IOS tersebut akan mempengaruhi nilai suatu perusahaan (Pagalung, 2003). Rasio nilai buku ekuitas terhadap nilai pasar (MVE/BVE) dapat mencerminkan adanya IOS bagi suatu perusahaan (Shintawati,2011). Rasio tersebut digunakan dengan mempertimbangkan pendapat Gaver dan Gaver (1993) bahwa nilai pasar dapat mengindikasi kesempatan perusahaan untuk bertumbuh dan melakukan kegiatan investasi sehingga perusahaan memperoleh pertumbuhan ekuitas dan aktiva. Market value to book value of equity (MVE/BVE) diukur melalui jumlah lembar saham beredar dikalikan closing price kemudian dibagi dengan total ekuitas. Secara matematis diformulasikan sebagai berikut:

$\mathrm{MVE} / \mathrm{BVE}=$ Jumlah lembar saham x Harga penutupan saham

Total ekuitas

Model Penelitian

Penelitian ini bertujuan melihat pengaruh antara variabel independen dan variabel dependen dengan skala pengukuran rasio dalam suatu persamaan linier, 
Jurnal Akuntansi Berkelanjutan Indonesia - Vol. 3, No. 2, Mei 2020 - Ruhiyat \& Holiawati

dalam penelitian ini digunakan analisis regresi yang sebelumnya melakukan uji asumsi klasik dan juga melakukan uji hipotesis. Analisi regresi digunakan untuk mengetahui pengaruh Public Ownership (X1), growth option (X2) terhadap kinerja keberlanjutan (Y) yang di moderasi public ownership (Z).

Keterangan:

$$
\mathrm{Y}=\mathrm{a}+\beta \mathrm{x} 1+\beta \mathrm{x} 2+\beta \times 1{ }^{*} \mathrm{z}+\beta \times 2{ }^{*} \mathrm{z}+\mathrm{e}
$$

$$
\begin{array}{ll}
\mathrm{Y} & =\text { Kinerja Keberlanjutan } \\
\mathrm{a} & =\text { Nilai Konstanta } \\
\beta & =\text { Koefisien Regresi (Beta) } \\
\mathrm{x} 1 & =\text { Public Ownership } \\
\mathrm{x} 2 & =\text { Growth Option } \\
\mathrm{z} & =\text { Investment opportunity Set } \\
\mathrm{e} & =\text { Standar Error }
\end{array}
$$

\section{ANALISIS DATA DAN PEMBAHASAN}

\section{Statistis Deskriptif}

\section{Tabel 1}

\section{Hasil Uji Statistik Deskriptif}

\begin{tabular}{lr|r|r|r|r} 
& N & Minimum & Maximum & \multicolumn{1}{c}{ Mean } & Std. Deviation \\
\hline PO & 50 & .05 & 1.00 & .3650 & .26775 \\
\hline GO & 50 & -2.70 & 82.44 & 8.4499 & 18.18744 \\
\hline KNRJKBRLNJTN & 50 & 30.71 & 70.71 & 51.3842 & 11.97884 \\
\hline IOS & 50 & -2.70 & 82.44 & 8.2858 & 18.24118 \\
\hline Valid N (listwise) & 50 & & & & \\
\hline
\end{tabular}

Hasil analisis deskriptif pada tabel 1 menunjukan bahwa jumlah observasi dari penelitian adalah sebanyak 50 pengamatan dengan menunjukan nilai minimum, maximum dan mean serta standart deviasi.

\section{Hasil Pengujian Uji Hipotesis}

Uji hipotetsis dapat dilihat pada tabel 4.2 merupakan uji regresi yang dilakukan untuk menguji Public Ownership dan Growth Option terhadap Kinerja Keberlanjutan dengan moderasi Investment opportunity Set.

Tabel 2 Hasil Pengujian Uji Hipotesis

Kinerja Keberlanjutan ${ }_{i t}=Y=a+\beta \times 1+\beta \times 2+\beta \times 1 z+\beta \times 2 z+e$ 
Jurnal Akuntansi Berkelanjutan Indonesia - Vol. 3, No. 2, Mei 2020 - Ruhiyat \& Holiawati

\begin{tabular}{|l|c|c|c|}
\hline Variabel & Prediksi & Koefisien & P-value \\
\hline Public Ownership & -39.371 & $.001 * * *$ \\
\hline Growth Option & 9.809 & $.074 * * *$ \\
\hline Investment opportunity Set & -11.151 & $.046^{* *}$ \\
\hline Moderasi IOS * PO & 10.746 & $.020 * *$ \\
\hline Moderasi IOS * GO & -.001 & .911 \\
\hline \multicolumn{2}{|c|}{ Durbin -Watson Stat } & 0.0000 \\
Probabilita F statistic & 0.171 \\
Adjusted R -squared & & \\
Total Observasi & & \\
\hline
\end{tabular}

Sumber : data diolah

\section{Pengaruh Public Ownership terhadap Kinerja Keberlanjutan}

Berdasarkan hasil penelitian yang diperoleh, dari hasil uji sig 0.001 dapat dijelaskan adanya pengaruh public ownership terhadap perubahan kinerja keberlanjutan. Hasil penelitian ini mendukung Manning, et al (2017) menemukan, bahwa Public Ownership berpengaruh signifikan terhadap Sustainability Performance dan mendukung Puspita (2014) menemukan, bahwa Growth Option dan Public Ownership berpengaruh positif terhadap Sustainability Performance.

Semakin besar proporsi kepemilikan saham publik, maka semakin banyak pihak yang membutuhkan informasi tentang perusahaan, sehingga banyak pula butir-butir informasi yang diungkapkan dalam laporan tahunan. Selain itu, semakin besar saham yang dimiliki oleh publik, maka semakin banyak informasi yang diungkapkan dalam laporan tahunan, investor ingin memperoleh informasi seluas-luasnya tentang tempat berinvestasi serta dapat mengawasi kegiatan manajemen perusahaan, sehingga kepentingan dalam perusahaan terpenuhi.

Public Ownership pada umumnya dapat bertindak sebagai pihak yang memonitor perusahaan. Perusahaan dengan kepemilikan publik yang besar (lebih dari 5\%) mengindikasikan kemampuannya untuk memonitor manajemen perusahaan. Semakin besar kepemilikan publik yang dimiliki oleh perusahaan maka semakin efisien pemanfaatan aktiva perusahaan dan diharapkan juga 
dapat bertindak sebagai pencegahan terhadap pemborosan yang dilakukan oleh manajemen.

Perusahaan yang sahamnya dimiliki oleh publik akan melakukan pengungkapan tanggung jawab sosial yang lebih besar daripada perusahaan yang sahamnya tidak dikuasai oleh publik, serta perusahaan yang sudah lama berdiri akan memiliki tanggung jawab sosial yang semakin besar, karena semakin tingginya kepercayaan investor dan masyarakat luas. Akibatnya, perusahaan harus memberikan informasi yang secara detail kepada investor dan masyarakat luas, tidak hanya berupa laporan keuangan tetapi juga berupa pengungkapan tanggung jawab sosial.

\section{Pengaruh Growth Option terhadap Kinerja Keberlanjutan}

Berdasarkan hasil penelitian yang diperoleh, dari hasil uji dengan signifikansi 0.074 bahwa adanya pengaruh growth option terhadap kinerja keberlanjutan. Pernyataan didukung penelitian terdahulu sebelumnya oleh Anita Ardiyani Puspita dan Daljono (2014) tentang analisis faktor-faktor yang mempengaruhi kinerja keberlanjutan perusahaan mengenai pengaruh ukuran perusahaan, leverage, profitabilitas, growth option, komitmen perusahaan, kepemilikan publik, dan umur perusahaan terhadap kinerja keberlanjutan perusahaan, yang menyatakan bahwa growth option berpengaruh positif terhadap kinerja keberlanjutan, ukuran perusahaan berpengaruh positif terhadap kinerja keberlanjutan, profitabilitas berpengaruh positif terhadap kinerja keberlanjutan, kepemilikan publik berpengaruh positif terhadap kinerja keberlanjutan, sedangkan leverage dan komitmen perusahaan berpengaruh terhadap kinerja keberlanjutan.

Dari pemaparan hasil tersebut bahwa jika perusahaan memiliki growth option yang baik maka akan semakin diperhatikan oleh stakeholdernya secara luas, sehingga menimbulkan legitimasi dari setiap stakeholder dimana perilaku organisasi perusahaan harus mampu melakukan kegiatan usahanya dengan memiliki batasan-batasan atas dasar norma, nilai sosial, dan reaksi terhadap adanya batasan tersebut kepada lingkungan baik internal maupun eksternal untuk memastikan bahwa aktivitas operasi yang dilakukan oleh perusahaan dapat berjalan dengan baik dan berkelanjutan. Hal ini yang dapat meningkatkan praktik kinerja keberlanjutan pada perusahaan.

\section{Public Ownership dan Growth Option terhadap Kinerja Keberlanjutan Dengan Moderasi Investment Opportunity Set.}

Berdasarkan hasil uji signifikansi 0.20 artinya Investment Opportunity Set mampu memoderasi pengaruh Public Ownership terhadap Kinerja Keberlanjutan. Berdasarkan hasil uji signifikansi 0.911 artinya Investment Opportunity Set tidak memoderasi pengaruh Growth Option terhadap Kinerja Keberlanjutan.

Dengan demikian dapat disimpulkan bahwa investment opportunity set yang dilakukan oleh manajemen dapat mempengaruhi kinerja keberlanjutan perusahaan. Investment opportunity set merupakan usaha yang dilakukan oleh manajemen perusahaan untuk melihat nilai kesempatan investasi yang 
merupakan nilai sekarang dari pilihan-pilihan bagi perusahaan untuk membuat investasi pada masa yang akan datang. Perusahaan haruslah mampu melihat kesempatan yang ada dan memanfaatkannya demi kemajuan serta peningkatan aktiva dan nilai investasi yang dimiliki di masa yang akan datang.

Hasil penelitian ini sejalan dengan penelitian Anggi Angga Resti (2018) yang menyatakan bahwasannya investment opportunity set berpengaruh terhadap kinerja perusahaan. Karena perusahaan yang memiliki IOS tinggi biasanya juga membutuhkan dana yang lebih besar untuk membiayai barang modal, dan akan mencoba untuk menemukan sumber-sumber di pasar modal. perusahaan tidak mau terlalu cenderung bergantung pada sumber pendanaan dari bank ketika nilai jaminan yang diadakan tidaklah mencukupi. Upaya agar perusahaan mendapatkan sumber dana dari pasar modal maka haruslah diduikung dengan kinerja akuntansi yang baik, jadi sudah barang tentu perusahaan haruslah berusaha untuk melalui kinerja yang positif melalui ROA yang baik kepada para calon investor. Hasil penelitian ini juga konsisten dengan penelitian yang dilakukan oleh Septiandi Dwi Nugraha (2016) yang menyatakan bahwa investment opportunity set berpengaruh secara signifikan terhadap kinerja perusahaan.

Namun hal yang berbeda dibuktikan dengan penelitian yang dilakukan oleh Marinda dkk, (2014) bahwa investment opportunity set tidak berpengaruh signifikan terhadap kinerja perusahaan yaitu karena menambahkan jumlah aktiva tidak selalu mempengaruhi kinerja keuangan sehingga dapat menyebabkan dana yang dimiliki perusahaan yang telah digunakan untuk menambahkan aktiva perusahaan tidak dapat digunakan untuk kegiatan perusahaan yang lebih efektif sehingga dapat meningkatkan kinerja dari perusahaan tersebut.

Dengan begitu dapat disimpulkan bahwasannya investment opportunity set berpengaruh terhadap kinerja keberlanjutan perusahaan karena tinggi rendahnya kinerja keberlanjutan dipengaruhi oleh investment opportunity set. Itu artinya, semakin tinggi investment opportunity set suatu perusahaan maka akan semakin tinggi dan baik pula kinerja keberlanjutan suatu perusahaan.

\section{KESIMPULAN DAN SARAN}

Penelitian ini mempunyai tujuan untuk menganalisa pengaruh public ownership dan growth option dan public ownership terhadap kinerja keberlanjutan dengan moderasi investment opportunity set pada perusahaan manufaktur yang terdaftar di Bursa Efek Indonesia (BEI) selama tahun 2013-2017. Mengacu kepada hasil penelitian yang telah dilakukan maka peneliti memperoleh hasil dari pengujian hipotesis terhadap seluruh variabel sebagai berikut:

1. Berdasarkan hasil uji hipotesis variabel public ownership yang diproksikan dengan kepemilikan saham publik (KSP), menyimpulkan bahwa variabel public ownership tidak berpengaruh terhadap kinerja keberlanjutan. Hal ini berarti untuk menjadi perusahaan yang melaksanakan praktik kinerja 
Jurnal Akuntansi Berkelanjutan Indonesia - Vol. 3, No. 2, Mei 2020 - Ruhiyat \& Holiawati

keberlanjutan, perusahaan tidak bergantung pada public ownership yang perusahaan tersebut miliki.

2. Berdasarkan hasil uji hipotesis variabel growth option yang diproksikan dengan price book value (PBV), menyimpulkan bahwa variabel growth option berpengaruh positif signifikan terhadap kinerja keberlanjutan. Hal ini disebabkan karena growth option yang besar dapat mendorong perusahaan dalam melaksanakan kinerja keberlanjutan.

3. Investment Opportunity Set mampu memoderasi pengaruh Public Ownership terhadap Kinerja Keberlanjutan. Investment Opportunity Set tidak memoderasi pengaruh Growth Option terhadap Kinerja Keberlanjutan.

Peneliti memberikan saran untuk penelitian selanjutnya

1. Perusahaan yang dipilih sebagai populasi dan sampel sebaiknya selain perusahaan manufaktur untuk dapat dijadikan acuan melakukan generalisasi pada seluruh perusahaan go public yang terdaftar di BEI.

2. Faktor-faktor yang mempengaruhi kinerja keberlanjutan perusahaan dalam penelitian ini hanya growth option, public ownership dan investment opportunity set sehingga perlu penambahan variabel lain untuk lebih menguatkan hasil penelitian.

3. Dalam penyajian laporan keuangan, perusahaan hanya menggunakan satuan nilai rupiah.

\section{DAFTAR PUSTAKA}

Artiach,T., Lee, D., Nelson, D., Walker,J. (2010) "The Determinant of Corporate Social Sustainability Performance”, .Journal of Accounting and Finance.

Bieker \& Waxenberger. (2002). Sustainability Balance Scorecard \& Business Ethics, Contribution to the 10th International Conference of the Greening of Industry Network, Göteborg/Sweden

Brundtland, G.H., (1987) "Report of The World Commission on Environment and Development". The United Nation.

Chen, Jian, (2001) "Ownership Structure as Corporate Governance Mechanism: Evidence from China listed Companies". Economics of Planning

Christina, Yessy Ni Putu dan Sunada, I Putu, (2013) "Penilaian Kinerja Pada PT. Aghi Karya Dengan Pendekatan Balanced Scorecard". E-Jurnal Akuntansi Universitas Udayana, 2013

Deegan, C., (2004) "Financial Accounting Theory". The McGraw-Hill Companies, Inc

Dwi, Septiandi N. (2016). Pengaruh Investment Opportunity Set (IOS) dan Good Corporate Governance (GCG) terhadap Kinerja Perusahaan. Skripsi

* Corresponding author's e-mail:holiawati76@gmail.com

http://openjournal.unpam.ac.id/index.php/JABI 
Jurnal Akuntansi Berkelanjutan Indonesia - Vol. 3, No. 2, Mei 2020 - Ruhiyat \& Holiawati

AkuntansiFakultas Ekonomi dan Bisnis Universitas Islam Negeri Syarif Hidayatullah Jakarta.

Fajrotus, Sufi Syifa. (2017). Pengaruh Investment Opportunity Set (IOS), Kepemilikan Institusional, Komisaris Independen, dan Return on Investment (ROI) terhadap Nilai Perusahaan pada Perusahaan Manufaktur yang Terdaftar di Bursa Efek Indonesia. Skripsi Fakultas Ekonomi. Universitas Negeri Yogyakarta

Figge F, Hahn T, Schaltegger S, Wagner M. (2001a). Sustainability Balanced Skorcard. Wertorientiertes Nachhaltigkeitsmanagement mit der Balanced Skorcard. Center for Sustainability Management: L"unebu

(2002). The Sustainability Balance Scorecard Linking Sustainability Management To Business Strategy. Business Strategy \& the Environment (pp. 269-284).

Freeman, R. E., (1984) "Strategic Management: A Stakeholder Approach". Boston : Pitman.

Ghozali, Imam dan Chariri, Anis, (2007) "Teori Akuntansi. Semarang : Badan Penerbit Universitas Diponegoro

Ghozali, Imam, (2011) "Aplikasi Analisis Multivariete Dengan Program SPSS", Semarang : Badan Penerbit Universitas Diponegoro

Ghozali, Imam, (2016) "Aplikasi Analisis Multivariete Dengan Program IBM SPSS 23", Edisi kedelapan, Semarang : Badan Penerbit Universitas Diponegoro

http://www.detiknews.com/

http://www.globalreporting.org

http://www.idx.co. id/

Huang, Pepper \& Bowrey. (2014). Implementing A Sustainability Balance Scorecardto Contribute To The Process Of Organisational Legitimacy Assessment. Australasian Accounting, Business \&Finance Jornal.Vol 8 issue 2

Kaplan R., Norton D. (1992). The Balanced Skorcard: Measures That Drive Performance. Harvard Business Review, No. 92105. 28

Kaplan, R. S. dan Norton, D. P., (1996) "Using The Balanced Scorecard as a Strategic Management System". Harvard Business Review 
Jurnal Akuntansi Berkelanjutan Indonesia - Vol. 3, No. 2, Mei 2020 - Ruhiyat \& Holiawati

Lourenco dan Manuel. (2013) "Determinants of Corporate Sustainability Performance in Emerging Markets : The Brazilian Case", Journal of Accounting and Financial.

Manning, Bart, Geert, dan Daniel. (2017). "Corporate Governance and Sustainable Business Conduct Effects of Board Monitoring Effectiveness and Stakeholder Engagement on Corporate Sustainability Performance and Disclosure Choices", Journal of Accounting and Finance.

Marinda, Fajrul. Moch Dzulkirom AR dan Muhammad Saifi. (2014). Pengaruh Investment Opportunity Set (IOS) dan Struktur Modal Terhadap Kinerja Keuangan. Jurnal Administrasi Bisnis (JAB) Vol. 14 No. 1 September 2014. Universitas Brawijaya Malang

McWilliam, Abagail and Siegel, Donald, (2000) "Corporate Social Responsibility: A Theory of the Firm Perspectiv," Academy of Management Review

Pradipta, Arka Budi Dharma. (2014). Analisis Pengaruh Investment Opportunity Set, Corporate Governance, Leverage, Ukuran Perusahaan, Kinerja Masa Lalu, dan Jenis Industri Terhadap Kinerja Perusahaan. Skripsi Fakultas Ekonomika dan Bisnis. Universitas Diponegoro Semarang

Prasetiyatno, Rachmad, dan Issa. (2011). "Pengukuran Kinerja Perusahaan dengan Metode Balanced Scorecard”, Jurnal Teknik Industri.

Puspita, Anitya dan Daljono. (2014). "Analisis Faktor-Faktor yang Mempengaruhi Corporate Sustainability Performance", Journal of Accounting.

Rahayu, Puji.(2015) "Pengaruh Kepemilikan Saham Publik, Profitabilitas dan Pengungkapan Media terhadap Pengungkapan Tanggung Jawab Sosial pada Perusahaan Property dan Real Estate”, Skripsi Akuntansi Fakultas Ekonomi Universitas Semarang.

Resti. (2018). Pengaruh Kebijakan Deviden dan Investment Opportunity Set (IOS) Terhadap Kinerja Perusahaan pada Perusahaan Go Public. Jurnal Ekonomi dan Bisnis, Vol. 5 No. 1, Januari - Juni: Hal, 43 - 58.

Sánchez, J.L.F., Sotorrío, L.L., Díez, E.B., (2011) “The Relationship BetweenCorporate Governance and Corporate Social Behavior.A Structural Equation Model Analysis.Corporate Social Responsibility and Environmental Management”. Journal International 
Jurnal Akuntansi Berkelanjutan Indonesia - Vol. 3, No. 2, Mei 2020 - Ruhiyat \& Holiawati

Sawir, A. (2000). Analisis kinerja keuangan dan perencanaan keuangan perusahaan. PT Gramedia Pustaka Utama, Jakarta.

Schaltegger S \&Wagner M. (2006a). Integrative Management of Sustainability Performance, Measurement \& Reporting, International Journal of Accounting, Auditing \&PerformanceEvaluation, Vol. 3, No. 1, pp. 1-19.

Schaltegger, S. \& T. Dyllick, (Eds.) (2002). Nachhaltig Managen Mit Der Balance Scorecard (To Manage Sustainably With the Balanced Skorcard), Wiesbaden: Gabler.

Sekaran, Uma, (2011) "Research Methods For Business (Metode Penelitian Untuk Bisnis)". Jakarta: Salemba Empat

Sugiyono, (2016) "Metodelogi Penelitian Kuantitatif, Kualitatif Dan R\&D" Bandung : Alfabeta

Sugiyono, (2017) "Statistika Untuk Penelitian". Edisi keduapuluh delapan. Bandung : Alfabeta

Suharto, Edi, (2008) “Kebijakan Sosial sebagai Kebijakan Publik” . Bandung : Alfabeta

Suriasumantri, Jujun S., (1992) "Filsafat Ilmu: Sebuah Pengantar Popoler". Jakarta: Sinar Harapan

Ullmann, A. A., (1985) "Data in Search of A Theory: A Critical Examination of the Relationships Among Social Performance, Social Disclosure, and Economic Performance of U.S. firms". United States : Academy of Management Review.

Vansiliette (2015). Planning Sustainability Strategies Through the SystemicDriven Sustainability Balanced Skorcard: the case of "The House" Project.

Watts, Ross L. dan Jerold L. Zimmerman, (1986) "Positive Accounting Theory". USA: Prentice-Hall 